\title{
UNIVERSITYOF
}

FORWARD

THINKING

WESTMINSTER用

WestminsterResearch

http://www.westminster.ac.uk/westminsterresearch

Parliamentary Oversight and Corruption in the Caribbean:

Comparing Trinidad \& Tobago and Grenada

Stapenhurst, F., Staddon, A., Draman, R. and Imbeau, L.

This is an accepted manuscript of an article published by Taylor \& Francis in Commonwealth and Comparative Politics, DOI: 10.1080/14662043.2018.1444933

The final definitive version is available online:

https://dx.doi.org/10.1080/14662043.2018.1444933

(C) 2018 Taylor \& Francis

The WestminsterResearch online digital archive at the University of Westminster aims to make the research output of the University available to a wider audience. Copyright and Moral Rights remain with the authors and/or copyright owners.

Whilst further distribution of specific materials from within this archive is forbidden, you may freely distribute the URL of WestminsterResearch: ((http://westminsterresearch.wmin.ac.uk/).

In case of abuse or copyright appearing without permission e-mail repository@westminster.ac.uk 


\section{PARLIAMENTARY OVERSIGHT \& CORRUPTION IN THE CARIBBEAN: TRINIDAD \& TOBAGO AND GRENADA COMPARED}

Frederick Stapenhurst, Anthony Staddon, Rasheed Draman and Louis M. Imbeau

(Submitted to Commonwealth and Comparative Politics, 2018)

\section{Introduction}

There had been little research on parliamentary oversight in the Caribbean. Hamid Ghany (1994, 1999, 2012) has written extensively on parliaments in the region, but his work has examined parliaments from an evolutionary and institutional perspective, rather than from a functional one. A few other scholars have focused on specific issues, such as human rights (Helfer, 2002), gender (Vassell, 2006), and constitutional matters (Barrow-Giles, 2010), but to date, little research has been undertaken on oversight. This is surprising, since perceived corruption levels are high in most Caribbean countries and because oversight has been found to be a major determinant of corruption Indeed, Stapenhurst, Pelizzo and Jacobs (2014) determined that variances in oversight capacity, including the political willingness of Members of Parliament (MPs) to ensure effective oversight, account for nearly half of the variation in perceived corruption across countries globally.

This article seeks to address this gap. Two Commonwealth Caribbean countries were chosen for analysis: Trinidad \& Tobago, as one of the 'larger' countries in the region, with a population in excess of two million, and Grenada, as one of the 'smaller' countries, with a population of around 100,000 . It is organized in the following way. In the first section, we briefly present the purpose of the article and our data sources. Then, we examine some of the contextual conditions that scholars have noted impact oversight. Thirdly, we consider the key oversight tools used, and focus in particular on Public Accounts Committees (PACs) which have a key role in scrutinizing public finance. We then examine some unique oversight approaches adopted in Trinidad \& Tobago and Grenada, which may be replicable elsewhere in the region. In the final section, we draw some conclusions, regarding both the generalization of our results and the implications for other Caribbean countries.

\section{Background: Corruption}

That corruption hinders development has been well documented (e.g. Mauro, 1997, Wei and Kaufmann, 1999, Kaufmann, 2000). In 2016, the Bahamas and Barbados were reported as having the lowest levels of perceived corruption (scoring 66 and 61 points, respectively, out of a possible 100) but even so they ranked $24^{\text {th }}$ and $31^{\text {st }}$ in the Transparency International Corruption Perceptions Index (CPI) of 176 countries (Transparency International, 2017). The highest levels of corruption were in Jamaica (39/100, ranking as the $83^{\text {rd }}$ most corrupt country), Trinidad and Tobago (35/100, ranking $\left.101^{\text {st }}\right)$, and Guyana (34/100, ranking $\left.106^{\text {th }}\right)$. Corruption has, according to the scores on the CPI index, deteriorated over the past five years for all countries in the region (Transparency International, 2016); see Chart 1.The exception is Grenada, which scored 56/100 and ranked $46^{\text {th }}$ 
most corrupt country in the world in 2016, compared with 68/100 and $79^{\text {th }}$ in 2007 (data for theChart 1: Transparency International Corruption Perceptions Index $(\mathbf{1 0 0}=$ extremely low; 0=extremely high corruption)

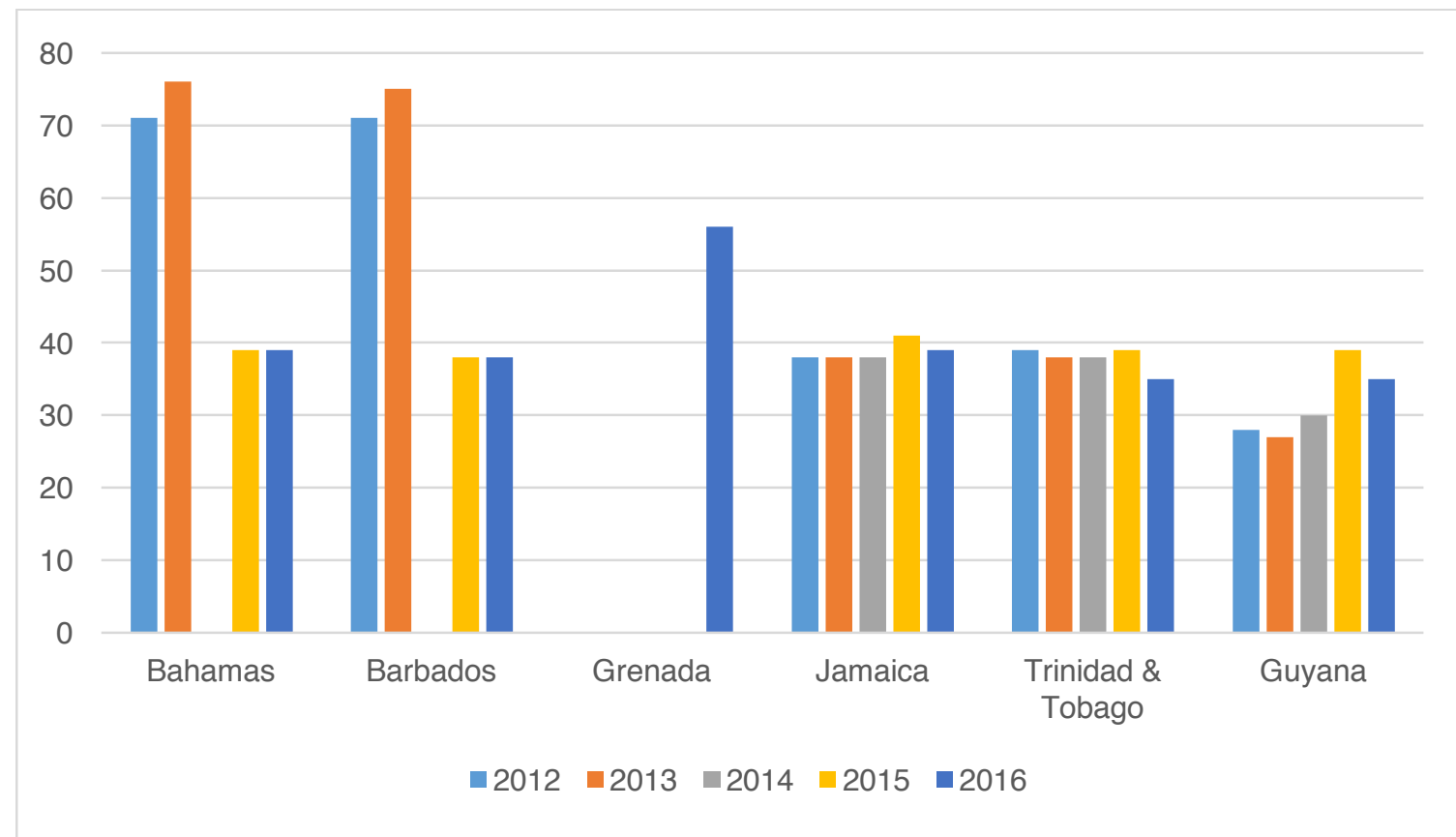

Bahama and Barbados, 2014 and Grenada 2012-2015: no data

Source: Transparency International (2017)

\section{Chart 2: Real GDP Growth 2012-17 (annual \%)}

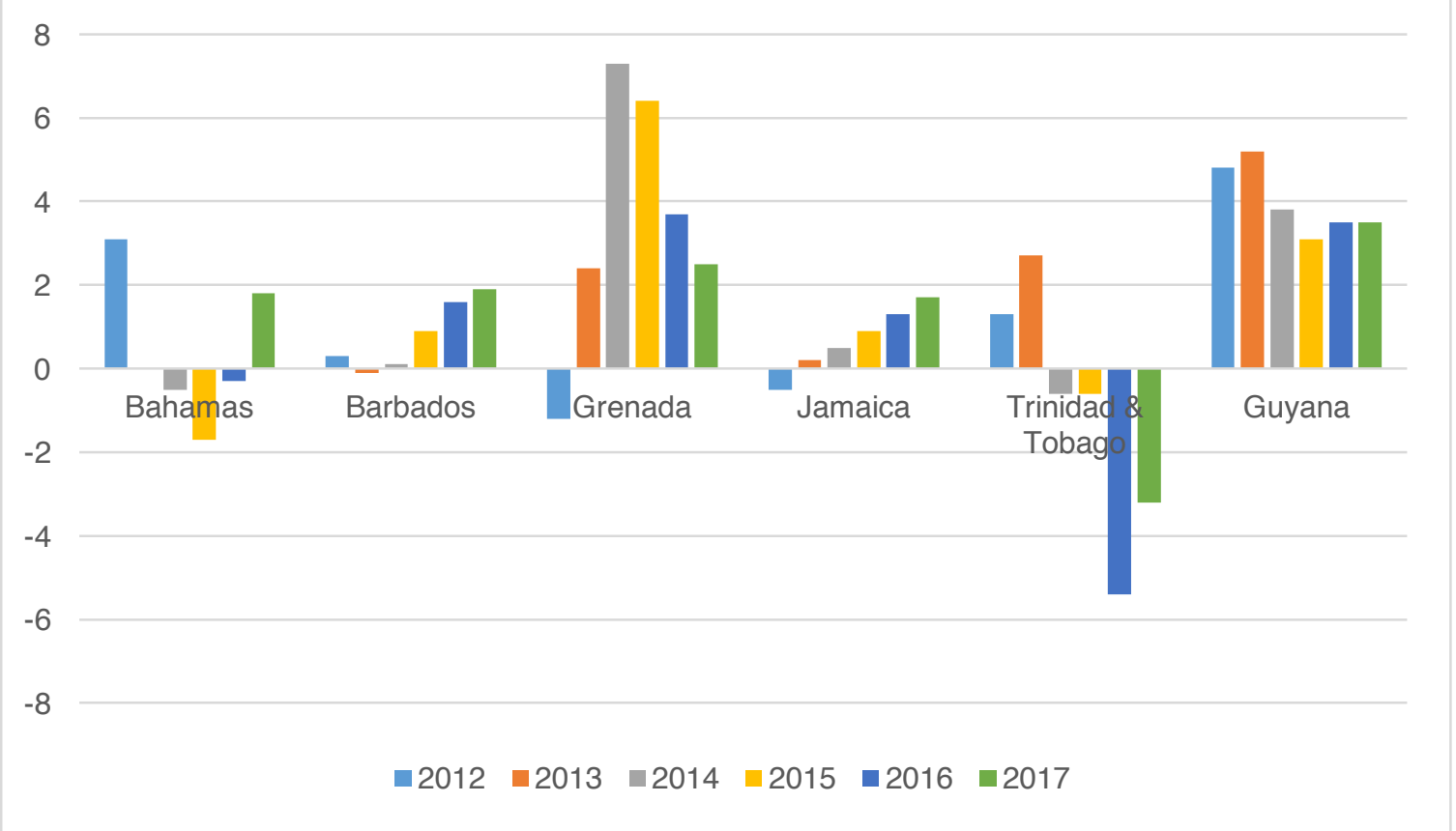

Source: World Data Atlas 
intervening years is not available). Corruption is an important issue, especially given that it has hindered economic growth and development; over the past five years, growth has been disappointing across the region, with the notable exceptions of Grenada and, to a lesser extent, Guyana (see Chart 2). Correlations of Caribbean countries' real GDP per capita growth and CPI scores over the past decade indicate a medium negative correlation (-0.3439). This supports Mauro's (1997) contention that a 20 point improvement in TI's CPI results in a 0.5 percentage point increase in GDP per capita growth.

\section{Trinidad \& Tobago}

According to the US Department of Commerce (2016), bribes are not regularly required to facilitate routine business operations, but reports of corruption are common there. Indeed, Victor Hart, chairman of the Trinidad \& Tobago Transparency Initiative, described the country as "a society of corruption" (Bruzual, 2010). Public perceptions of corruption have increased amidst “...such [scandals] as the Urban Development Corporation of Trinidad \& Tobago (UDECOTT) scandal...[where] the Executive Chairman was surrounded with corruption charges stemming from the biased granting of millions of dollars of contracts and from personally benefitting from such contracts" (Kirton and Niki, 2010) and reports on breaches on tendering procedures by the Trinidad and Tobago Electricity Commission in relation to jobs under the company's Street Lighting and Implementation Unit.

Various laws address corruption of public officials, including the Integrity in Public Life Act, the Prevention of Corruption Act, and the Police Complaints Authority Act. But implementation of legislation is a problem: allegations of corruption seldom work through the legal system, resulting "...in a scarcity of cases with legal outcomes", with "...procurement processes [that are] not fully transparent [and that] government ministries bypassed or manipulated established procurement procedures to favor specific vendors" (US Department of Commerce, 2016, p.1-2). There has been serious concern over public procurement for many years; it was a factor in the downfall of the 2001 and 2010 governments. A Procurement Bill was passed in 2015 which established the Office of Procurement Regulation to act as the governing body for matters relating to public procurement and the retention and disposal of public property.

\section{Grenada}

The Prevention of Corruption Act and the Integrity in Public Life Act, the legislative core of Grenada's anticorruption efforts, were both passed in 2007 while a decree passed in 2013 under the Integrity in Public Life Act that mandated all public officials declare their personal assets by April 3, 2014.

Transparency International (2016) reported progress and high levels of corruption; this finding drew mixed responses. Jude Bernard (2017) stated that “...there is widespread institutionalized corruption in our society. It is at the point where people have gotten so accustomed to it being that way, that they just more or less accept it. Sometimes we simply refer to it as 'just politics'." By contrast, the Integrity Commission and the Finance Intelligence Unit said "For our part, such a 
listing is surprising, given that Grenada has made significant and consistent strides in strengthening its anti-corruption mechanism over the past five years" (Straker, 2017).

\section{Purpose and Data}

This article aims to present our research findings on parliamentary oversight in the Trinidad \& Tobago and Grenada, thereby at least partially addressing the gap in knowledge of oversight in the Caribbean. If the causal path that higher levels corruption adversely affects economic development, and that enhanced parliamentary oversight can mitigate corruption (Stapenhurst, Pelizzo and Jacobs, 2014) holds true for the Caribbean, these findings should prove useful to parliamentarians, development practitioners and general citizens seeking to boost development in the region.

Data were collected from two sources: First, we collected field data in January 2017. This comprised an in-country document search and 39 key informant interviews (9 MPs/Senators; 8 journalists; 11 parliamentary staff and 8 civil society representatives) using a survey instrument initially developed by Stapenhurst (2011) and revised for the British Academy/United Kingdom's Department for International Development's Anti-Corruption Evidence research program. Second, we utilized data from a survey of more than 100 legislatures globally conducted in 2015-6 by the Inter-Parliamentary Union; this enabled us to triangulate our results and make some global inferences.

\section{Setting the Stage: Trinidad \& Tobago and Grenada - Contextual Factors}

Wang (2005), echoing Olson and Mezey (1991) and Olson and Norton (1996), claimed that contextual factors determined the effectiveness of parliamentary oversight tools and mechanisms. Building on her framework, Stapenhurst (2011) identified 10 contextual factors impacting oversight. These are used as a framework for analysis in this section.

\section{Size, Population and Economy}

It has been suggested by Fisman and Gatti (2000), Treisman (2000) and Knack and Azfar (2000) that larger countries are more corrupt than smaller ones. ${ }^{1}$ While both Grenada and Trinidad \& Tobago are, by global standards, small, the latter is, by Caribbean standards, a fairly large state (1,981 square miles) with a population of 1.3 million. Furthermore, Trinidad \& Tobago as a significant oil industry, a relatively large economy and a GDP per capita of around US 32,000. Grenada, by contrast, is geographically much smaller (134 square miles), less populated $(110,000)$

\footnotetext{
${ }^{1}$ While the eight countries reported by Transparency International to have the lowest levels of corruption globally namely Denmark, New Zealand, Finland, Sweden, Switzerland, Norway, Singapore and the Netherlands - are all 'small', the dispersion of 'very small' countries is greater, with Luxembourg ranking $11^{\text {th }}$, Iceland $14^{\text {th }}$, Bahamas $24^{\text {th }}$ and Bhutan $27^{\text {th }}$.
} 
and poorer (GDP per capita of US 13,600). Trinidad \& Tobago is ethnically diverse (35\% Indian, $34 \%$ African), while Grenada is more homogenous (89\% African).

There is a strong, positive and significant relationship between economic wealth, which is one of the indicators of development, and corruption. In other words, countries that are richer are less corrupt (Pelizzo and Stapenhurst, 2004). The data presented in Table 1 shows that while both countries are middle-income countries, the GDP per capita is two and a half times higher in Trinidad \& Tobago than in Grenada and, therefore, should be associated with, and possibly conducive, to less corruption.

Several studies, including those undertaken by the World Bank (Mody, 2004), indicate that small countries tend to be less corrupt than large countries. Large countries may present administrative challenges, create conditions for inefficiency, effectiveness and misallocation of resources. Both Trinidad \& Tobago and Grenada are small, but it is perhaps reasonable to hypothesize that Grenada is less corrupt because of its very small size.

\section{Colonial Heritage}

Treisman (2000) noted that a country's colonial heritage impacts corruption; more specifically, he noted that former British colonies have lower levels of corruption than former colonies of other European countries. Both Trinidad \& Tobago and Grenada were claimed by Spain, but there is no record of the Spanish landing in Grenada. French colonization of Grenada began in 1650 but in 1763 Grenada was ceded to the British whose rule continued, except for brief French rule (177984), until 1974. By contrast, the Spanish settled in Trinidad and Tobago as early as the mid$16^{\text {th }}$.century and ruled the country through 1797 when it was seized by the British. From 1958 to 1962 both countries were part of the Federation of the West Indies ${ }^{2}$. Trinidad \& Tobago became independent in 1962.

\section{Elections, Government}

Persson, Tabellini and Trebbi (2001) proposed that countries with majoritarian ('first past the post' or FPTP) electoral systems tend to have lower levels of corruption than countries with proportional representation (PR) systems, because the former creates a direct link between voters and politicians. Kunicova and Rose-Ackerman (2005) concurred. Both Trinidad \& Tobago and Grenada have two chambers: a lower House of Representatives elected on a FPTP electoral system (FPTP) and Senate whose members are appointed by the head of state. In Trinidad \& Tobago, 16 Senators are appointed on the advice of the Prime Minister, six Senators on the advice of the Leader of the Opposition and nine Senators to represent other sectors of civil society (the only function the President of the Republic of Trinidad and Tobago takes without consultation) while in Grenada

\footnotetext{
${ }^{2}$ A short-lived federation comprising Anguilla, Antigua \& Barbuda, Barbados, the Cayman Islands, Dominica, Grenada, Jamaica, Montserrat, Saint Kitts and Nevis, Saint Lucia, Saint Vincent and the Grenadines, Trinidad \& Tobago and the Turks and Caicos Islands
} 
seven Senators are appointed on the advice of the Prime Minister, three by the Opposition Leader and three to represent other sectors of society.

Since both Trinidad \& Tobago and Grenada have majoritarian electoral systems, and appointed Senators, this factor cannot be used to explain differences in corruption.

Generally, it is thought that political competitiveness and effective opposition parties help constrain corruption (e.g. Schleiter and Voznata, 2012). ${ }^{3}$ There is currently no opposition representation in the House of Representatives of Grenada, since all 15 seats were won by the New National Party ${ }^{4}$. As a result, it is perhaps reasonable to expect Trinidad \& Tobago to be less corrupt, because of the prominence of an opposition party in its parliament.

In both Trinidad \& Tobago and Grenada, parliamentarians who serve as Ministers are full-time; all other Members are part-time. This results in a significant difference in salaries between Ministers, on the one hand, and back-bench and Opposition MPs, on the other. One implication for oversight may be that MPs (and Senators) who hold part-time positions and pursue careers outside of parliament may not have sufficient time to undertake their oversight responsibilities (Stapenhurst, 2016).

\section{Political Parties}

Both countries have a two-party system ${ }^{5}$, although in Trinidad \& Tobago a third emerged recently (but has no seats in parliament).

It is not entirely clear to what extent party strength may affect a parliament's ability to effectively perform oversight and thus impact the level of corruption (Pelizzo and Stapenhurst, 2014). Party strength may be measured in votes, seats, income, age and party cohesion - characteristics that may or may not go together. Furthermore, there are contradictory claims as to whether strong partisanship is beneficial to the effectiveness of oversight activity. For instance, Rockman (1984) and Beetham (2006) suggest that a high level of partisanship is beneficial to oversight because when the opposition parties are mobilized against the ruling party, both they and parliament are more likely to effectively perform their watchdog and oversight functions. This line of thinking holds the view that government members will not take their oversight tasks seriously because their primary interest is to protect their government. But this view neglects the fact that across the

\footnotetext{
${ }^{3}$ Although they argue that larger numbers of political parties hamper effective accountability and give greater scope for corruption.

${ }^{4}$ A proposal to amend the Constitution to ensure that there will always be a Leader of the Opposition in the House of Representatives was defeated in a referendum in November 2015.

${ }^{5}$ The People's Partnership in Trinidad is a political coalition comprising four political parties: the United National Congress, the Congress of the People, the Tobago Organization of the People, the National Joint Action Committee.
} 
Commonwealth, parliamentarians have an institutional, as well as a partisan affiliation; in addition to having loyalty to their party they also have loyalty to the institution of parliament. ${ }^{6}$

It is difficult to say whether - and to what extent - political parties affect the parliaments of Trinidad \& Tobago and Grenada in oversight. Our field research shows an interesting phenomenon: while the current governing party in Grenada is stronger than its Trinidadian counterparts (Table 1), the responses from our survey respondents revealed that party cohesion is stronger in Trinidad, with a mean score of 4.4 (i.e., 'fairly strong') than in Grenada, where party cohesion has a mean score of 3.4 (i.e., 'neither weak nor strong')! However, one Grenadian Parliamentarian explained to us "political parties portray themselves as strong, even if in practice there are problems and tensions internally". There was greater agreement among Trinidadian respondents regarding the degree of partisanship, but less so among Grenadians, with parliamentary staff suggesting that the degree of partisanship is 'strong' to 'very strong' and civil society and media respondents suggesting it is 'neither weak nor strong'. Nonetheless, given the lack of consensus noted above, these results cannot provide a clear indication of which legislature should be a more effective overseer and thus be better equipped to curb corruption.

One explanation for the results from Grenada is the experience of the 2008-13 Government which had a large parliamentary majority (11 out of 15 seats) but which was not united and had five cabinet resignations. The first resignation was demanded by the Prime Minister and involved the Attorney General who used his office to plead on behalf of a family member facing criminal charges in the United States. On the one hand, the resignation sent a positive anti-corruption signal. However, the episode sparked unrest within the governing party and four subsequent Cabinet Ministers resigned in protest at the Prime Minister's leadership, and the fallout was a factor in the eventual defeat of the government and in the loss of all their seats in the House of Representatives. This episode demonstrates how the resignation or sacking of a Cabinet Minister in a very small country can disproportionately impact the government, which may act as a disincentive for a Prime Minister to take a strong stand against corruption. In such instances, the importance of effective parliamentary oversight is heightened if malfeasance is to be thwarted.

\footnotetext{
${ }^{6}$ The loyalty that legislators have for the institution is quite clear in the case of PACs, whose success have been credited, above all, to parliamentarians' ability to work in a non-partisan fashion (McGee, 2002; Stapenhurst et al, 2005; Stapenhurst, Pelizzo and Jacobs, 2014).
} 
Table 1: Political Party Dynamics

(Scale of 1-5, where for Q 9, 1 = very weak, and 5 = very strong)

\begin{tabular}{|c|c|c|c|c|c|}
\hline $\begin{array}{l}\text { Survey } \\
\text { Question } \\
\text { Number }\end{array}$ & Survey Question & $\begin{array}{l}\text { Trinida } \\
\text { Tobago } \\
\text { Mean } \\
\text { Score }\end{array}$ & $\begin{array}{l}\text { \& } \\
\text { Std. } \\
\text { Dev. }\end{array}$ & $\begin{array}{l}\text { Grena } \\
\text { Mean } \\
\text { Score }\end{array}$ & $\begin{array}{l}\text { Std. } \\
\text { Dev }\end{array}$ \\
\hline \multirow[t]{5}{*}{9} & How Strong is Political Party Cohesion & 4.4 & 0.6 & 3.4 & 1.2 \\
\hline & $\begin{array}{l}\text { How Strong is Political Party Cohesion } \\
- \text { MPs \& Senators }\end{array}$ & 4.3 & 0.5 & 4.0 & 0.0 \\
\hline & $\begin{array}{l}\text { How Strong is Political Party Cohesion } \\
\text { - Parliamentary Staff }\end{array}$ & 4.4 & 0.5 & 4.7 & 1.2 \\
\hline & $\begin{array}{l}\text { How Strong is Political Party Cohesion } \\
\text { - Civil Society }\end{array}$ & 4.0 & 0.6 & 3.5 & 1.3 \\
\hline & $\begin{array}{l}\text { How Strong is Political Party Cohesion } \\
\text { - Journalists }\end{array}$ & 4.5 & 0.0 & 3.0 & 0.0 \\
\hline
\end{tabular}

A further factor linked to corrupt activity in both jurisdictions is the absence of any regulations or restrictions on the amount parties can raise or spend for elections. In Trinidad \& Tobago, political parties are not formally recognized by statute and they are not legally required to adhere to any regulations regarding campaign finance. A similar situation exists in Grenada where spending limits for individual candidates are based on the number of registered voters in a constituency. A proposed bill to establish an independent Elections and Boundaries Commission, which could have at least partially addressed this issue, was rejected in a referendum in Grenada in November 2015 (Parliament of Trinidad and Tobago, 2015).

\section{Trust in Parliament}

Wang (2005) noted the importance of public trust in parliament if oversight is to be effective. Data is not available for Grenada, but data from the World Value Survey indicates that public trust in the Parliament of Trinidad \& Tobago is low - in 2010-14, only 25.9 percent of respondents reported having 'a lot' or 'some' trust in parliament, a lower percentage than that reported in the armed forces, the government, the civil service, the courts, the press or the police. However, this trust (in parliament) is significantly higher than in 2001-06, when only $15.7 \%$ of respondents reported having 'a lot' or 'some' trust in parliament. This suggests that the emphasis placed on public outreach and communications by the Parliament of Trinidad \& Tobago is at least helping restore what has been called 'the democratc deficit' (Stapenhurst, 2011, Smith, 2004). 
Given the lack of data for Grenada, this factor cannot be used to explain the differences in corruption between the two countries, but remains a relevant factor for other countries where such data is available.

\section{Conclusion}

Clearly, the evidence for Trinidad \& Tobago and Grenada suggests that contextual factors alone cannot, as previously suggested (Wang, 2005; Stapenhurst, 2011), explain differences in parliamentary oversight (and hence corruption) - in Trinidad \& Tobago and Grenada. The data is indeterminate: on the basis of country size, population and economy, Grenada might be expected to have lower corruption, while on the basis of government and opposition parties, Trinidad \& Tobago should have lower corruption; the other factors are indeterminate. As a result, we turn to oversight tools and supporting factors.

\section{Oversight Tools}

A decade ago, Pelizzo and Stapenhurst (2006) argued that in order to understand why democracy works better in some countries than others, a focus shift from general, macro-level characteristics to meso-level characteristics was needed. In other words, in order to understand the functioning of a political system or institution, one needed to examine the institution's powers and not just its general characteristics. In the case of parliaments and parliamentary oversight, they suggested that our understanding of whether and to what extent parliaments can effectively perform their oversight tasks would increase if more attention is paid to the number and the type of oversight tools available to parliaments.

There is considerable similarity between the legislature in Trinidad \& Tobago and Grenada: both have Public Accounts Committees (PAC), Question times, motions of censure, and established procedures for votes of no confidence. They also both have a Supreme Audit Institution, Ombuds offices and anti-corruption agencies, but only Trinidad \& Tobago has a significant library, 'good' research facilities and strong staff support. The committee system is also more developed in Trinidad and Tobago. The evidence (Table 2), therefore, supports the claim that Trinidad \& Tobago has greater oversight capacity than Grenada. 
Table 2: Oversight Capacity - Oversight Tools and Facilitating Conditions (Summary)

\begin{tabular}{|l|l|l|}
\hline Oversight Tools- Internal & Trinidad \& Tobago & Grenada \\
\hline Audit Committees & Public Accounts Committee & Public Accounts Committee \\
\hline Other Committees & $\begin{array}{l}\text { Relatively strong; well } \\
\text { resourced }\end{array}$ & $\begin{array}{l}\text { Tend to be weak; poorly } \\
\text { resourced }\end{array}$ \\
\hline Question Period & Yes & Yes \\
\hline $\begin{array}{l}\text { Cabinet } \\
\text { Formation/Dismissal }\end{array}$ & No & No \\
\hline Vote of No Confidence & Yes & Yes \\
\hline Oversight Tools-External & & Audit Department \\
\hline Supreme Audit Institution & Auditor General & Yes \\
\hline Ombuds Office & Yes & $\begin{array}{l}\text { Integrity Commission } \\
\text { Financial Intelligence Unit }\end{array}$ \\
\hline Anti-Corruption Agencies & $\begin{array}{l}\text { Integrity Commission } \\
\text { Anti-Corruption }\end{array}$ & Investigation Bureau \\
\hline Facilitating Conditions & & Poor \\
\hline Staff + Research Facilities & Good & Pending \\
\hline Access To Information Law & Yes & \\
\hline
\end{tabular}

It is not just the existence of oversight tools that is important but also their effectiveness (Pelizzo and Stapenhurst, 2014). We consider the perceived effectiveness of the oversight tools in the following sections, but we conflate internal and external tools, since the operations of PACs (an internal tool) and Auditors General (an external tool) are symbiotic: the work (and effectiveness) of the PAC depends on the work and effectiveness of the Auditor General, and vice versa.

Parliamentary oversight is perhaps especially important with regard to public spending, in what is often called Parliamentary 'Power of the Purse', Parliamentary oversight of public spending is commonly divided into ex-ante (legislative involvement in budget formulation (i.e., the drafting and legislative stages) oversight and ex-post oversight (the implementation and audit phases). As Diagram 1 shows, parliaments play important roles in the legislative and audit stages of the budget process; both Trinidad \& Tobago and Grenada follow this process. 


\section{Diagram 1}

\section{Stages of the annual budget process}

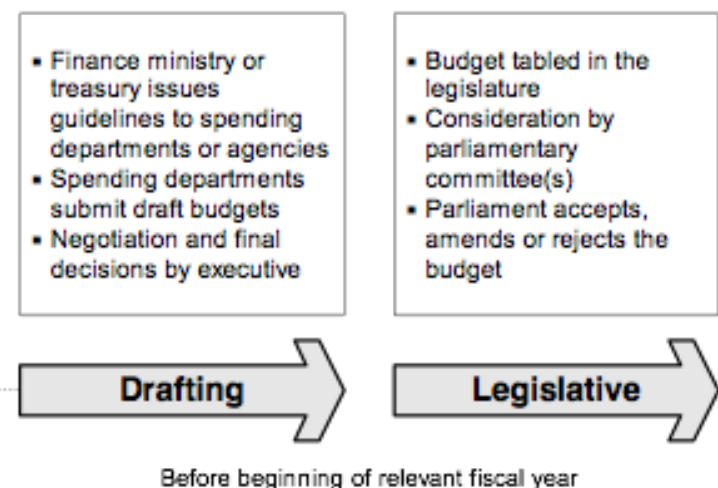

Before beginning of relevant fiscal year

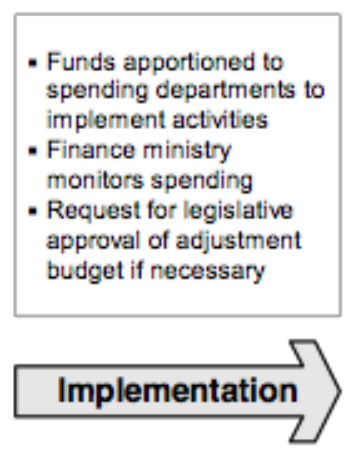

Fiscal year starts and ends

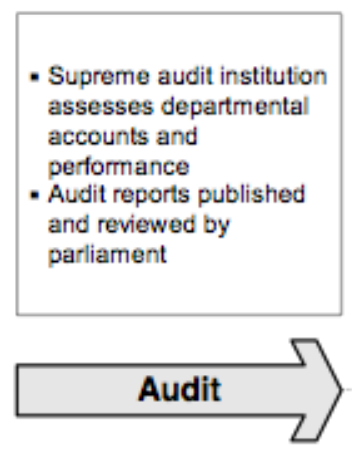

Following end of fiscal year

Source: Wehner (2004)

Wehner (2010) notes that parliaments in the Westminster tradition ${ }^{7}$ tend to have weak ex-ante oversight powers, while Stapenhurst, Eboutou and Jacobs (unpublished) argue that such parliaments have strong ex-post oversight. While the Parliament of Trinidad and Tobago has taken recent steps to strengthen its ex-ante oversight powers - principally through changes to the operation of the Standing Finance Committee, the creation of a new Committee on Public Administration and Appropriations - the current lack of an Opposition in Grenada's House of Representatives reinforces the fundamental weakness of ex-ante oversight in countries with a Westminster-style parliament.

In Westminster parliamentary systems - the most common in the Caribbean - the legislative auditor is the Auditor General and a core element of parliamentary oversight. He/she reports directly to parliament and the PAC and is sometimes even an officer of parliament, guaranteeing independence from the executive (Stapenhurst, Pelizzo and Jacobs, 2014). The relationship between the Auditor General and the PAC in this model is crucial: the effectiveness of the PAC depends on timely audit reports while an effective PAC ensures the impact of legislative audit.

In short, parliament confers responsibilities to the executive arm of government, which is accountable to parliament. The auditor's mandate, to examine the accounts and, increasingly, performance of government, is determined by parliament; the Auditor reports his/her findings to parliament, in order to take action.

\footnotetext{
${ }^{7}$ Most Commonwealth countries, with the notable exceptions of Nigeria and Guyana
} 


\section{Public Accounts Committees}

Both Trinidad \& Tobago and Grenada have PACs, but with significant differences in operations and effectiveness. As Table 3 indicates, the PAC in Trinidad \& Tobago meets more frequently ( 7 or 8 times a year) than the PAC in Grenada (3 times a year). The Trinidadian PAC was judged to be slightly better than half-way between very ineffective and very effective' (with a mean of 3.1 out of 5) in uncovering fraud and corruption, with MPs, Senators and civil society representatives rating the committee as somewhat more effective, with mean scores of 3.3 each, and journalists rating it somewhat less effective, with a mean score of 2.8. By contrast, the Grenadian PAC was judged to be 'ineffective', (mean score of 1.9 out of 5), with parliamentary staff rating it somewhat higher (mean of 2.8: about half way between very ineffective and very effective) and civil society as lower (1.0: 'very ineffective'). What causes these differences? In both countries, the PAC is chaired by a member of the Opposition ${ }^{8}$, but the degree of partisanship in the committee is considered to be higher in Grenada (mean of 3.8:'somewhat strong') compared with Trinidad \& Tobago (mean of 3.6 out of 5: half-way between 'neither weak nor strong' and 'somewhat strong'). There was general consensus on the scoring among respondents in Trinidad \& Tobago, although civil society representatives thought the degree of partisanship to be somewhat higher (mean: 4.2, signifying somewhat higher than 'strong' compared with an overall average of 3.6, midway between 'neither weak nor strong' and 'strong') but in Grenada journalists thought the committees to be much more partisan (4.3: midway between 'strong' and 'very strong'). Overall, these results - that the PAC in Trinidad \& Tobago is more effective than the PAC in Grenada, are consistent with McGee (2002), who pointed out that effective PACs were those that acted in a non-partisan manner.

The most recent Public Expenditure and Financial Accountability Assessment (PEFA) written by Wiggins and Shepherd (2010) gave Grenada the lowest possible score ('D') for the legislative scrutiny of audit reports, noting that only one PAC report had been presented to the House during the 2006-08 period, and no public hearings or recommendations issued by the House in response to reports by the Auditors. Survey respondents suggest that little has changed over the past decade; indeed things are less transparent as the PAC has met in camera since 2003.

While Trinidad \& Tobago only scored somewhat better ('D+') in overall legislative scrutiny of audit reports, it scored a little better (' $\mathrm{C}$ ') regarding public hearings and recommendations made by the House to the government as a result of the audit report (Quist, 2008). Moreover, the recent strengthening of the parliamentary committee system in Trinidad \& Tobago, and the establishment of a PAC-like Committee on Public Enterprises, suggests the potential for improvement in oversight of public finance (Stapenhurst, 2016), although no recent assessment has been undertaken.

\footnotetext{
${ }^{8}$ In Grenada, by the leader of the Opposition in the Senate
} 
Table 3: Committees and Commissions

(Scale of $1-5$, where $1=$ very weak and $5=$ very effective)

\begin{tabular}{|c|c|c|c|c|c|}
\hline \multirow{2}{*}{$\begin{array}{l}\text { Survey } \\
\text { Question } \\
\text { Number }\end{array}$} & \multirow[t]{2}{*}{ Survey Question } & \multicolumn{2}{|c|}{$\begin{array}{l}\text { Trinidad \& } \\
\text { Tobago }\end{array}$} & \multicolumn{2}{|c|}{ Grenada } \\
\hline & & $\begin{array}{l}\text { Mean } \\
\text { Score }\end{array}$ & $\begin{array}{l}\text { Std. } \\
\text { Dev. }\end{array}$ & $\begin{array}{l}\text { Mean } \\
\text { Score }\end{array}$ & $\begin{array}{l}\text { Std. } \\
\text { Dev. }\end{array}$ \\
\hline \multirow[t]{10}{*}{20} & $\begin{array}{l}\text { Effectiveness of the PAC* in Uncovering Incidents of } \\
\text { Fraud and Corruption }\end{array}$ & 3.1 & 1.1 & 1.9 & 1.1 \\
\hline & $\begin{array}{l}\text { Effectiveness of the PAC* in Uncovering Incidents of } \\
\text { Fraud and Corruption - MPs \& Senators }\end{array}$ & 3.3 & 1.0 & 2.0 & 1.2 \\
\hline & $\begin{array}{l}\text { Effectiveness of the PAC* in Uncovering Incidents of } \\
\text { Fraud and Corruption-Staff }\end{array}$ & 3.0 & 0.8 & 2.8 & 1.3 \\
\hline & $\begin{array}{l}\text { Effectiveness of the PAC* in Uncovering Incidents of } \\
\text { Fraud and Corruption-Civil Society }\end{array}$ & 3.3 & 1.4 & 1.0 & \\
\hline & $\begin{array}{l}\text { Effectiveness of the PAC* in Uncovering Incidents of } \\
\text { Fraud and Corruption - Journalists }\end{array}$ & 2.8 & 1.7 & 1.3 & 0.5 \\
\hline & $\begin{array}{l}\text { Effectiveness of Special Commissions in Uncovering } \\
\text { Incidents of Fraud and Corruption }\end{array}$ & 2.9 & 1.6 & 2.6 & 1.0 \\
\hline & $\begin{array}{l}\text { Effectiveness of Special Commissions in Uncovering } \\
\text { Incidents of Fraud and Corruption-MPs \& Senators }\end{array}$ & 3.0 & 1.4 & 3.0 & 1.4 \\
\hline & $\begin{array}{l}\text { Effectiveness of Special Commissions in Uncovering } \\
\text { Incidents of Fraud and Corruption-Staff }\end{array}$ & 2.4 & 1.5 & 4.0 & \\
\hline & $\begin{array}{l}\text { Effectiveness of Special Commissions in Uncovering } \\
\text { Incidents of Fraud and Corruption-Civil Society }\end{array}$ & 3.0 & 1.8 & 2.0 & \\
\hline & $\begin{array}{l}\text { Effectiveness of Special Commissions in Uncovering } \\
\text { Incidents of Fraud and Corruption - Journalists }\end{array}$ & 3.3 & 2.1 & 2.0 & 0.0 \\
\hline \multirow[t]{2}{*}{16} & $\begin{array}{l}\text { Degree of Partisanship Within Legislative Oversight } \\
\text { Committees }\end{array}$ & 3.6 & 1.0 & 3.8 & 1.0 \\
\hline & $\begin{array}{l}\text { Degree of Partisanship Within Legislative Oversight } \\
\text { Committees - MPs \& Senators }\end{array}$ & 3.3 & 1.5 & 3.8 & 1.3 \\
\hline
\end{tabular}




\begin{tabular}{|l|l|l|l|l|l|}
\hline & $\begin{array}{l}\text { Degree of Partisanship Within Legislative Oversight } \\
\text { Committees - Staff }\end{array}$ & 3.3 & 0.8 & 3.7 & 0.6 \\
\hline & $\begin{array}{l}\text { Degree of Partisanship Within Legislative Oversight } \\
\text { Committees - Civil Society }\end{array}$ & 4.2 & 1.0 & 2.0 & \\
\hline & $\begin{array}{l}\text { Degree of Partisanship Within Legislative Oversight } \\
\text { Committees - Journalists }\end{array}$ & 3.3 & 0.6 & 4.3 & 0.5 \\
\hline & How often do oversight committees meet & $\begin{array}{l}7-8 \\
\text { times }\end{array}$ & - & $\begin{array}{l}3 \\
\text { times }\end{array}$ & - \\
\hline
\end{tabular}

* in Trinidad \& Tobago, respondents were asked 'How effective is the PAC and other oversight committees [such as the Committee on Public Enterprises and the Joint Select Committees]...

The Joint Select Committees (JSCs) in Trinidad and Tobago are empowered to inquire and report to both Houses of Parliament regarding government ministries, Municipal Corporations, Statutory Authorities, State Enterprises and Service Commissions. The Parliament has taken steps to remove discrepancies between Senate and House Standing Orders and the JSCs. It has also established new JSCs: Government Assurances, Public Appropriation and Administration, National Security, Energy Affairs, Foreign Affairs, and Human Rights, Diversity and Environment and Sustainable Development.

While the JSCs are only able to scrutinize some of the policies and actions of government departments and agencies with limited outputs and outcomes from their work (Staddon, 2013), some survey respondents suggested that they are becoming more effective in bringing corruption issues to the agenda. Significantly, the JSCs are chaired by independent Senators which has undoubtedly helped the committees and reduced partisanship. There has also been an increase in inquiries and JSC-reports laid by the three established JSCs in the last Parliament (Office of the Parliament, 2015).

\section{Other Committees of Inquiry}

Both countries have established special committees or commissions of inquiry. Again, the Trinidadian committees were judged as more effective than the Grenadian ones in uncovering incidents of fraud and corruption (the former, essentially mid-way between very ineffective and very effective (2.9/5) and the latter somewhat less effective (2.6/5)). Only one such Commission has been set up in Grenada, in 2008 to investigate the Prime Minister who was alleged to have received money in response to an appointment (he was cleared). 


\section{Auditor General}

A major difference between the two countries is the organization and mandate of the auditor. In Trinidad \& Tobago, the Auditor General was created in 1962, and is appointed by the President, after consultation with the Prime Minister and the Leader of the Opposition. The Auditor General is independent of government and reports directly to Parliament. In Grenada, by contrast, the Director of Audit, also enshrined in the Constitution, is appointed by the Governor-General on the advice of the Public Service Commission (who is appointed by the Governor-General, on the advice of the Prime Minister).

While the perceived effectiveness of the auditor is essentially the same in both countries ("neither effective nor ineffective" "), there is more agreement among Trinidadian participants (with MPs and Senators rating the effectiveness slightly lower, and journalists somewhat higher) than among Grenadians (where MPs and Senators voted the Director's office as "somewhat effective" and journalists as "somewhat ineffective'). In both countries, participants noted that the key constraint to audit effectiveness was the lack of action for Parliament to make or follow up on government recommendations. See Table 4.

These findings, of similar responses in the two countries, are surprising, since the Grenadian Audit Office has considerably less autonomy than does the Auditor General in Trinidad \& Tobago. In Grenada, the constitution requires that the Director of Audit submit reports to the Minister of Finance, who forwards to the House of Representatives, while in Trinidad \& Tobago, the Auditor General reports directly to Parliament. Both audit offices lack independence in hiring staff (they rely on the Public Service Commissions in their countries), and as a result are often under-staffed, under-funded and lack qualified auditors. In Trinidad and Tobago, survey respondents criticized the Auditor General's reports for not being adequately probing with more serious recommendations, rather than just highlighting minor items or small transgressions.

In Grenada, audit reports are often not addressed by Parliament in a timely manner. In both countries, Audit Office access is problematic, especially when government departments fail to respond to requests for documentation. In Trinidad \& Tobago, this is the case for statutory bodies. The requirement for public servants to explain themselves is especially ineffective in Grenada, where the PAC does not meet frequently.

\footnotetext{
${ }^{9}$ Respondents noted that, even where the Auditor may be doing good work in ensuring financial probity and in uncovering cases of fraud and corruption, unless the PAC and the Government have the political will to correct the problems found, the impact will be limited.
} 
Table 4: Auditor General

(Scale of $1-5$, where $1=$ very weak and $5=$ very effective)

\begin{tabular}{|l|l|l|l|l|l|}
\hline \multirow{2}{*}{$\begin{array}{l}\text { Survey } \\
\text { Question } \\
\text { Number }\end{array}$} & Survey Question & \multicolumn{3}{|l|}{$\begin{array}{l}\text { Trinidad \& } \\
\text { Tobago }\end{array}$} & \multicolumn{2}{l|}{ Grenada } \\
\hline 12 & $\begin{array}{l}\text { Mean } \\
\text { Score } \\
\text { Effectiveness of the Auditor General in Uncovering } \\
\text { Incidents of Fraud and Corruption }\end{array}$ & $\begin{array}{l}\text { Std. } \\
\text { Dean } \\
\text { Score }\end{array}$ & $\begin{array}{l}\text { Std. } \\
\text { Dev. }\end{array}$ \\
& $\begin{array}{l}\text { Effectiveness of the Auditor General in Uncovering } \\
\text { Incidents of Fraud and Corruption - MPs \& } \\
\text { Senators }\end{array}$ & 3.0 & 0.8 & 4.4 & 0.5 \\
\hline & $\begin{array}{l}\text { Effectiveness of the Auditor General in Uncovering } \\
\text { Incidents of Fraud and Corruption - Staff }\end{array}$ & 3.1 & 0.9 & 2.8 & 2.1 \\
\hline & $\begin{array}{l}\text { Effectiveness of the Auditor General in Uncovering } \\
\text { Incidents of Fraud and Corruption - Civil Society }\end{array}$ & 3.2 & 1.3 & 2.5 & 1.4 \\
\hline & $\begin{array}{l}\text { Effectiveness of the Auditor General in Uncovering } \\
\text { Incidents of Fraud and Corruption - Journalists }\end{array}$ & 3.5 & 1.1 & 2.0 & 1.1 \\
\hline
\end{tabular}

In Trinidad \& Tobago financial regulations stipulate that financial reports be submitted to the Auditor General. A person who contravenes is fined. However, the sum is so small it fails to act as a deterrent. It is also unclear whether procedures are in place to enforce this.

These findings run counter to PEFA assessments, which generally are much more positive. In Grenada, the overall score regarding scope, nature and follow-up of external audits was B+, with a score of A given for the submission of reports to the National Assembly in a timely manner and B for most audit recommendations, especially value-for-money, being accepted by the auditees (Wiggins and Shepherd, 2010). Trinidad \& Tobago scored slightly worse - B for the scope and nature of the audit reports, timely submission of reports to Parliament and response by auditees. The principal problem was that there was no evidence of follow-up on corrective measures by the Executive in response to the Auditor General's recommendations (Quist, 2008). The reason for the discrepancy between the PEFA assessments and our own results may simply be a deterioration since the time of the PEFA assessments, nearly a decade ago, and our own research, or it may be that the PEFA assessments are based on a small number of indicators while our survey revealed broader opinions and perceptions. 
The Parliament of Trinidad and Tobago has begun to improve follow-up measures by revising its Standing Orders in June 2015. Previously, there was no requirement for a 60-day response from the executive for PAC reports if the report were debated/adopted. A Government Assurances committee has also been established to scrutinize Ministerial commitments on the floor of the House.

\section{Question Time}

So both countries have Question Time. In Trinidad \& Tobago, it was judged to be somewhat more effective (mean score of 2.9/5: mid-way between very ineffective nor very effective) than in Grenada, where it was considered 'somewhat ineffective' (mean score of 2.3/5); see Table 5. Respondents believed that the opposition had equal time as the government backbenchers to ask questions in both parliaments, similar to findings of other Commonwealth countries. Unanswered questions and delays in answering questions was raised as a concern in Grenada. The higher improved rating in Trinidad and Tobago may be caused by the introduction of the Prime Minister's Question Time in the $10^{\text {th }}$ Parliament (2010-2015). Over the entire 10th Parliament, more than 600 questions were filed in the House of Representatives, and $84 \%$ were answered. In the Senate more than 400 questions were filed, and $80 \%$ were answered (Office of the Parliament, 2015).

\section{Table 5: Question Period}

(Scale of $1-5$, where $1=$ very ineffective and $5=$ very effective)

\begin{tabular}{|l|l|l|l|l|l|}
\hline & & \multicolumn{3}{|l|}{$\begin{array}{l}\text { Trinidad \& } \\
\text { Tobago }\end{array}$} & \multicolumn{2}{l|}{ Grenada } \\
\hline $\begin{array}{l}\text { Survey } \\
\text { Question } \\
\text { Number }\end{array}$ & Survey Question & $\begin{array}{l}\text { Mean } \\
\text { Score }\end{array}$ & $\begin{array}{l}\text { Std. } \\
\text { Dev. }\end{array}$ & $\begin{array}{l}\text { Mean } \\
\text { Score }\end{array}$ & $\begin{array}{l}\text { Std. } \\
\text { Dev. }\end{array}$ \\
\hline $26 \mathrm{a}$ & $\begin{array}{l}\text { How Effective is Question Period in Uncovering } \\
\text { Incidents of Fraud and Corruption }\end{array}$ & 2.9 & 1.1 & 2.3 & 1.3 \\
\hline $26 \mathrm{c}$ & $\begin{array}{l}\text { Does the Opposition Have Equal Time to Ask } \\
\text { Questions }\end{array}$ & 1.1 & 0.2 & 1.0 & 0.0 \\
\hline
\end{tabular}

\section{Censure and No Confidence}

The Trinidad \& Tobago interviewees reported that while the legislature has the power to censure Ministers or the Prime Minister, it rarely does. Westminster convention holds that government requires the confidence of the lower house, which is the practice in both countries. This noconfidence motion is symbolic because the government's majority means that it is unlikely to be removed, but it does raise crucial issues regarding governance. There are, however, examples of 
success. In 2010, the threat of a motion of no-confidence against then Trinidad and Tobago Prime Minister Patrick Manning, led to him calling a general election, in which the ruling People's National Movement (PNM) was defeated.

In Grenada, the government can use the Constitution to avoid a vote of no-confidence. It states that Parliament must sit at least once per year with no more than 6 months passing between sittings. This allows any government to sideline Parliament and delay parliamentary business, including votes of confidence. This was the course of action taken by the previous Prime Minister in 2012 to help him escape a no-confidence vote against his leadership style.

One controversial innovation in Trinidad \& Tobago in the last Parliament was a government motion of no confidence in the then Leader of the Opposition, Dr. Rowley. Using a motion of no confidence against the Leader of the Opposition is a dubious use of parliamentary procedure such a motion is always likely to be approved because of the government's majority, leading to a suspension from Parliament - the highest level of sanction imposable by the House. Ultimately it was a defeat for the government, which lost the subsequent election and Dr Rowley became Prime Minister.

\section{Ombudsman, Integrity Commissions, \& Anti-Corruption Agencies}

At least in part to due to encouragement from external organizations such as the Commonwealth Secretariat and the Mechanism for Follow-Up on the Implementation of the Inter-American Convention Against Corruption, both Trinidad \& Tobago and Grenada have established Ombudsman offices and other anti-corruption agencies.

\section{Ombudsman}

Both Trinidad \& Tobago and Grenada have Ombudsman offices designed to assist individuals who believe that they suffered maladministration within the public service.

In Trinidad \& Tobago, the Ombudsman office, established in 1976, has extensive investigatory powers. He/she can enter and inspect any jurisdictional premises and can call for, examine and retain any document there and pursue investigations under the Ombudsman's functions. He/she has High Court judicial powers to summon witnesses compelled to give evidence under oath. To help ensure independence, the Ombudsman is an Officer of Parliament, only accountable to Parliament, submitting annual performance and results reports and making special reports to Parliament.

The Ombudsman office in Grenada is much newer, established in 2007. The Ombudsman does not report to Parliament, but its investigative reports may be laid in Parliament by the appropriate Minister. In 2017 the mandate of the Office is expanded to include human rights, become the National Human Rights Office (Straker, 2017). 
Survey respondents in neither country believe the Office of the Ombudsman is especially effective. In Trinidad \& Tobago, it was considered just above 'somewhat ineffective' and in Grenada, 'neither effective nor ineffective' (Table 5). In Trinidad \& Tobago there is a lack of awareness of the roles, function and existence of the Ombudsman. Indeed, respondents were generally unaware of

the

Ombudsman.

\section{Integrity Commissions}

The Integrity Commission in Grenada established in 2007 upholds public officials to high standards of integrity through declarations of assets, liabilities, income and interests and it investigates impropriety, corruption and misconduct by public officials, prosecuting guilty people.

The Integrity Commission in Trinidad \& Tobago has a broader mandate. Its roles include prevention and investigation of corruption, enforcement and public education. It also receives declarations of income, assets and liabilities, and is responsible for examining the practices and procedures of public bodies to facilitate discovery of corrupt practices.

Respondents often confused Integrity Commissions with other anti-corruption agencies, considered below. Regardless respondents did not judge the effectiveness of the Integrity Commissions or anti-corruption agencies very highly (Table 6): in both, they ranked at the lower end of 'between somewhat ineffective' and 'neither effective nor ineffective'.

Table 6: External Oversight Institutions

(Scale of $1-5$, where $1=$ very ineffective and $5=$ very effective)

\begin{tabular}{|l|l|l|l|l|l|l|}
\hline & & \multicolumn{3}{|l|}{$\begin{array}{l}\text { Trinidad \& } \\
\text { Tobago }\end{array}$} & \multicolumn{2}{l|}{ Grenada } \\
\hline $\begin{array}{l}\text { Survey } \\
\text { Question } \\
\text { Number }\end{array}$ & Survey Question & $\begin{array}{l}\text { Mean } \\
\text { Score }\end{array}$ & $\begin{array}{l}\text { Std. } \\
\text { Dev. }\end{array}$ & $\begin{array}{l}\text { Mean } \\
\text { Score }\end{array}$ & $\begin{array}{l}\text { Std. } \\
\text { Dev. }\end{array}$ \\
\hline $16 \mathrm{~d}$ & $\begin{array}{l}\text { Effectiveness of the Ombudsman in Uncovering } \\
\text { Incidents of Fraud and Corruption }\end{array}$ & 2.2 & 1.6 & 2.3 & 1.1 \\
\hline $17 \mathrm{~d}$ & $\begin{array}{l}\text { Effectiveness of the anti-corruption agency in } \\
\text { Uncovering Incidents of Fraud and Corruption }\end{array}$ & 2.6 & 1.6 & 3.2 & 1.6 \\
\hline
\end{tabular}

In Grenada, there is an overlapping mandate between the Integrity Commission, the Public Service Commission and the Police. The Commission has demonstrated good practice in terms of intergroup information sharing between high-level government authorities and now needs to build an effective public outreach and education program. 
Trinidad \& Tobago's Commission has adopted measures to strengthen its work. Nonetheless, respondents reported that a large backlog of work remains, which is due to a lack of human and financial resources.

\section{Anti-corruption agencies}

The other anti-corruption agencies, the Anti- Corruption Investigation Bureau (AICB) in Trinidad \& Tobago and the Financial Intelligence Unit in Grenada, were not ranked better: midway between 'somewhat ineffective' in Trinidad \& Tobago and slightly above 'neither effective nor ineffective' in Grenada (Table 6), with some respondents unaware of the AICB's work. In Grenada the FIU is concerned with money laundering and counter terrorist financing, not anti-corruption per se. Survey respondents noted that the work of anti-corruption agencies is undermined by the time it takes to complete investigations and the time it takes to enforce sanctions through the courts.

\section{Facilitating Factors}

Stapenhurst (2011) and Pelizzo and Stapenhurst (2014) noted the importance of facilitating factors, which reinforce parliamentary oversight, notably information and research capacity, distinguishing between within-parliament library facilities and more general access to information.

\section{Library and Research Facilities}

The Parliaments of both Trinidad \& Tobago has relatively good library and research facilities while in Grenada these resources are limited, as the parliamentary library was damaged by hurricane. Respondents were united in believing that library facilities were underused: 'never used' by MPs and Senators in Trinidad \& Tobago, they reported, and 'rarely' in Grenada.

However, a Fiscal Scrutiny Unit has recently been established in Trinidad \& Tobago, which is likely to increase the timeliness of budget and fiscal analyses to MPs and Senators and should result in enhanced oversight of public finances.

\section{Access to Information}

Access to information (ATI) laws provide citizens and interested parties with the right to access government documents without having to show legal interest. Robinson and Milko (1994) noted that the need for information increases as a legislature progresses from rubber-stamping to an informed or transformative institution. Mendel (2005) posits that such laws can make it easier for legislators and researchers to obtain information otherwise hard to find, thereby assisting them in carrying out parliamentary oversight. Islam (2006) shows that countries that have not enacted ATI 
legislation record higher levels of corruption, although Taveres (2007) qualifies this by finding that it is not the mere enactment of legislation which matters, but rather its implementation.

As the Global Right to Information Rating project, backed by the Centre for Law \& Democracy and Access !Nfo, point out, there is substantial variation in the quality of ATI laws across the Caribbean: the Cayman Islands, the best in the region, score 112 out of a possible 138, while Guyana, the lowest, scores $69^{\text {th }}$. Trinidad \& Tobago score 89 and rank $50^{\text {th }}$ out of 111 countries. See Chart 3. It should be noted, however, that most Caribbean countries have not enacted ATI laws and that Grenada has a draft law, yet to be passed by Parliament.

\section{Chart 3: Right to Information Scores}

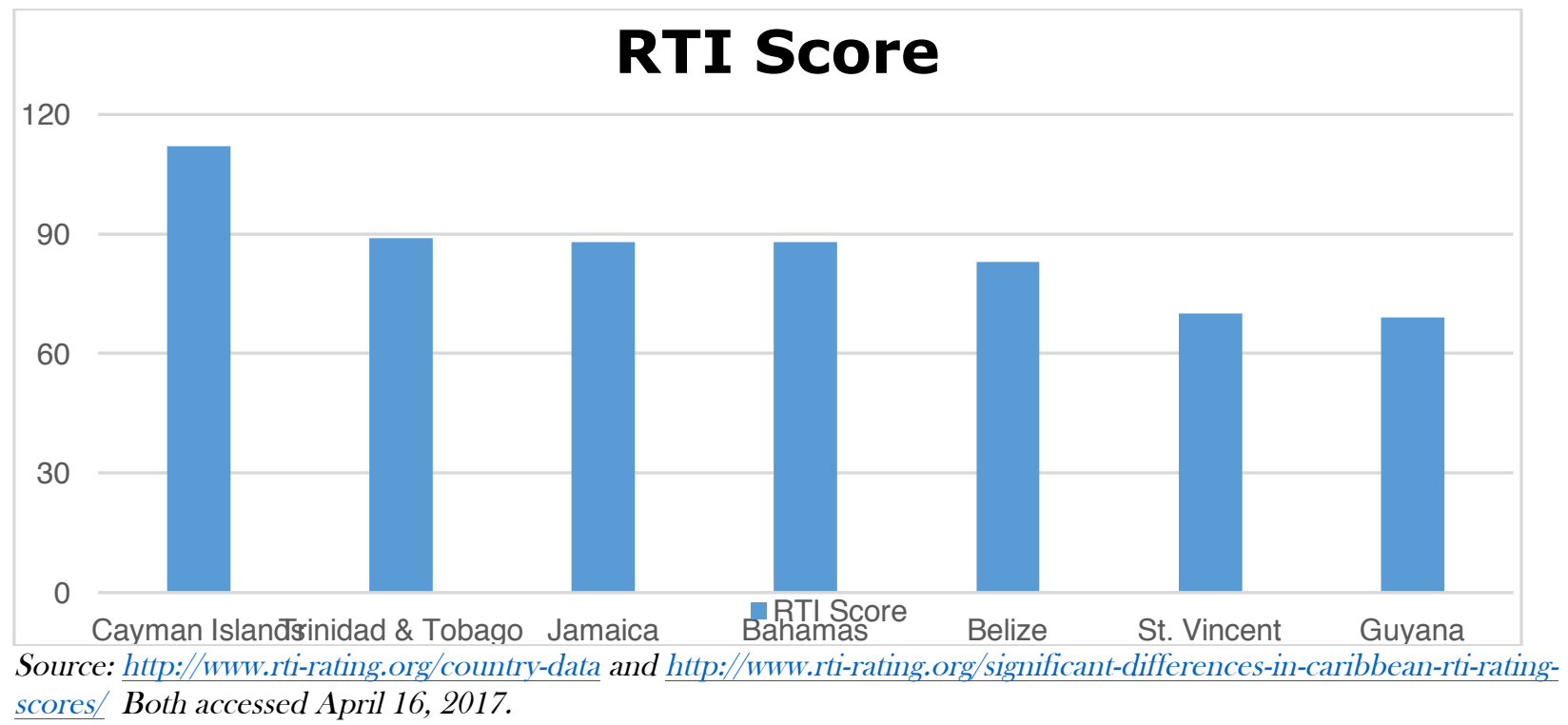

Trinidad \& Tobago passed the Freedom of Information Act in 1999 (implemented in 2001); the Ombudsman's office oversees implementation of the Act. According to RTI, Trinidad \& Tobago's law has several strengths, including a broad scope and somewhat effective promotional mechanism. However its biggest weakness is that, rather than a specialist body, appeals against refusals are channeled to the Ombudsman office, which lacks the structural framework to effectively perform this function. Other problems include vague rules surrounding fees and many exceptions provided for in the legislation. The responsiveness of agencies to FOI requests is not uniform. Some agencies do not provide information unless a court order is made. 
An FOI request by the civil group Fixin $\mathrm{T}+\mathrm{T}$ tied employees in constituency offices with nepotism and resulted in a revision in these procedures as well as a dismissal of a minister for breaching the Parliament's guidelines on the matter. This highlights the potential of FOI in exposing corruption and how CSO activity can assist in investigating and reporting wrong-doing.

\section{Other Oversight Mechanisms}

The Senate in both countries plays an important oversight role, especially in Grenada without a lower chamber opposition Member. As noted above, in Table 3, in Trinidad \& Tobago six Senators are appointed on advice from the Leader of the Opposition and nine Senators to represent other sectors of civil society, while in Grenada three of thirteen Senators are appointed on the advice of the Leader of the Opposition and three more to represent other sectors of society. Thus, while Government has a majority in the upper chamber, the Opposition party is represented as are cross sections of society.

In Grenada, the Government has launched a Committee of Social Partners (CSP) through which the Prime Minister can solicit advice and feedback from different elements of society on policies and draft laws. The CSP meets monthly and is comprised of representatives of the private sector, the trade unions, NGOs, religious organizations and youth. The CSP presents an Annual Report to Parliament for debate. While the objective of the CSP is not to oversee government, respondents spoke positively of this innovative approach to governance.

\section{Recommendations}

Before making recommendations for enhanced oversight tools, some consideration of trust in parliament is warranted. How can trust in parliament be increased? As noted in Table 5, public trust in Trinidad \& Tobago's Parliament is low: according to World Values Survey, only 25.9\% of respondents reported having 'a lot' or 'some' trust in parliament, lower than in other public institutions, but higher than 2001-06, when only $15.7 \%$ of respondents reported having 'a lot' or 'some' trust in parliament.

What are the causes of this improvement? Parliament is now more operationally efficient and more effective in citizen communication. There is a code of conduct and public declaration of assets by MPs and more transparency in parliamentary deliberations, including committee meetings, and improving budget oversight.

Support from the Speaker of the House and President of the Senate is well entrenched, but maybe difficult to officially facilitate when legislatures do not have control over staff recruitment, and especially of the senior public servant, the Clerk of Parliament. High turnover among parliamentary service people is common in many countries, but in Trinidad \& Tobago the Clerk has been in post for over 15 years. Her long experience in office and commitment to Parliament 
has enabled her to argue with the executive and given her the authority to work around public service constraints by offering a more favorable package to capable staff on a short-term contractual basis. The Clerk is a key factor in parliamentary strengthening over the last 10 years. On Grenada, by contrast, the current Clerk is a recent appointee of government, and he has not been able to play as proactive a role as has the Clerk in Trinidad \& Tobago.

\section{Making Oversight Tools More Effective}

Both Trinidad \& Tobago and Grenada have a full array of oversight tools; the issue is making these tools effective. Again, the recommendations need to be country-specific.

Having an effective committee system is necessary. While committees have been strengthened in Trinidad \& Tobago (with regular committee meetings and public hearings, and adequate administrative and research support), effectiveness is limited by part-time MPs. In Grenada the committee system is under-developed. The Finance Committee meets as a Committee of the Whole, leaving partisan politics to the Chamber. Since the number of backbench MPs to serve on committees is limited, certain facets of 'the Westminster' system should be relaxed:

$>$ Committee membership should comprise MPs and Senators

$>$ Ministers should be allowed to sit on Committees, and where necessary chair committees - but not committees that oversee their departments

$\triangleright$ Committee membership should include appointees from the public at large

$>$ Clerks and researchers (the latter perhaps as interns) should be provided to support committees.

The CSP in Grenada performs a useful function, although it is not a substitute for parliamentary oversight. The Prime Minister chairs the CSP and there is no official opposition representative on the body. This forum has not had a focus on oversight or corruption. Closer links between the CSP and Parliament would be useful, particularly with a new parliamentary building expected to be open during 2018 .

PACs should have the power to subpoena documents and witnesses, should promote 'government accountability' and should strive to increase public involvement (McGee, 2002). In Grenada, in the current absence of any Opposition Members in the lower House, the Chair of the PAC is the ranking Opposition Senator, which makes committee operations and achieving a bipartisan approach difficult, given his responsibilities as leader of the Opposition.

A workshop held in Port of Spain to consider oversight in the Caribbean concluded that small parliaments establish a body of unelected, apolitical officials with a public audit background to 
review audit reports by local governments. Such a body, in effect, 'ad hoc PAC', could examine Audit reports, call witnesses and make recommendations to the parliamentary PA.C which would review the work and issue an endorsement to the advisory committee's report. The workshop also suggested that small countries in the Caribbean, like Grenada, establish a 'regional PAC' so that potential synergies can be developed and support systems established and rationalized (ParlAmericas, 2014).

Having an effective, independent Auditor General is also important. Generally, it is recommended that Auditors General have the mandate to report key findings publicly with user-friendly reports, and that the PAC know the Auditor's budget and work plans (ParlAmericas, 2012).

More specifically, the Auditor-General in Trinidad \& Tobago should be empowered to impose administrative sanctions on government departments, agencies and statutory bodies that do not submit their financial reports on time. 'Naming and shaming' could also help, with the Auditor General publishing a list of non-compliant agencies and statutory bodies. The AG office also needs independence in hiring, promoting and firing staff, and not be dependent on the Public Service Commission (PSC), which in the past has taken 2-4 years to recruit staff (MESICIC, 2013); this could be achieved by the delegation of authority by the PSC. Parliament should also consider legislating the global Extractive Industries Transparency Initiative (EITI), which seeks to enhance the transparency of payments from extractive companies to governments, into the country's laws to ensure EITI forms part of the legal framework and provides an independent assessment of the revenues and payments declared by government and the extractive companies.

In Grenada, the Audit Department should be able to send its reports directly to Parliament, and not through the Department of Finance, as at present. Working with the PAC, the Department could better inform the public of their work, activities and outcomes, especially relating to corruption. And again, the Audit Office should be able to hire staff independently. There could also be a vehicle for developing linkages between the Audit Department and the CSP, with the aim of establishing channels for social audit.

Perhaps the biggest problem regarding ombudsman offices is that public servants, and the general public, are generally unaware of their existence. Outreach activities and public education activities should be enhanced and, in Trinidad \& Tobago, Parliament itself could assist, given its communications expertise.

Adequate budgets and financial autonomy were noted as problems. While ombudsman offices, like other public bodies, need to accept and operate within fiscal reality, Parliaments in both countries could help ensure that the ombuds offices have some financial independence. This degree of autonomy is important, especially if the Ombudsman is investigating complaints about the Ministry of Finance. Autonomy in human resource management is also desirable. 
It would seem useful, too, if the ombuds offices could establish time frames for public agencies to respond to their requests for information, and also have appropriate noncompliance enforcement mechanisms. Public outreach and communications strategies are also required, including training for public officials on their responsibilities under the Code of Conduct.

In Trinidad \& Tobago, the Commission is required to forward any breaches of Codes of Conduct to Parliament and to the Director of Public Prosecution to take appropriate disciplinary action but the institutions are not well coordinated. A formal information exchange should be established between the Commission and relevant agencies. Similarly, in Grenada collaborative arrangements need to be made between the Commission and the Financial Intelligence Unit, the Audit Department and the Director of Public Prosecutions (MESICIC, 2014). The Integrity Commissions need more access for prompt judgments. Whistleblower legislation may also prove useful in the fight against corruption and provide protection for individuals when exposing corruption.

Again, like the ombudsmen offices, the Commissions lack the power to impose administrative sanctions and financial and human resource autonomy. Parliaments should review these issues to ensure that the Commission is adequately resourced with financial autonomy. Grenada needs Parliament to have a stronger role in the appointment of the heads of constitutional watchdogs. Especially given the current lack of opposition voice in the House, the focus should be on the Senate to review and approve such appointments, as is the case in many countries with presidential forms of government. Given concerns about conflict of interest in small institutions, a non-citizen could be appointed as head of the Integrity Commission in both jurisdictions. While such a move has not, to our knowledge, been taken before, there are precedents of Auditors General who are citizens of another Commonwealth country being appointed; e.g. John Doyle, the Auditor General of British Columbia from 2007-2013 is an Australian citizen.

There are some further measures that the legislatures in both countries should prioritize, including a tougher parliamentary code of conduct, ethics committees, and using CPA benchmarks on Codes of Conduct. MPs and integrity commissions should fully and regularly disclose their financial assets and business interests. This would help generate and demonstrate a culture of accountability, thereby potentially raising public trust in parliaments. In terms of the issue of campaign financing and political party registration, the Organization of American States has developed a Model Law for Caribbean countries which provides transparency and accountability guidance; again, the adoption of such a law could boost public trust. Finally, one area that has caused recent controversy in Trinidad \& Tobago has been the use of constituency offices which are paid by the parliament, but under the control of Members. Members should be required to publish reports on how this money is spent, thereby allaying public fears that the funds are used for re-election or personal purposes. 


\section{Conclusions}

The research regarding parliamentary oversight in corruption in Trinidad \& Tobago and Grenada presents some interesting and surprising conclusions. We group these under three main headings: parliamentary oversight and corruption; executive dominance of parliament; and the challenges and solutions to parliamentary oversight in small states.

\section{Parliamentary Oversight and Corruption}

First, with regard to the causal chain between oversight and corruption, our results cast doubt on the results of previous research (e.g., Wang, 2005, Olson and Norton, 1996), which indicated that contextual factors were the principal determinant of differences in parliamentary oversight (and hence corruption). The results presented here do not support previous findings: in fact, it is rather inconclusive: on the basis of country size, population and economy, Grenada might be expected to have lower corruption, while on the basis of government and opposition parties, Trinidad \& Tobago should have lower corruption; the other factors are indeterminate.

Secondly, our results also cast doubt on the earlier results (Pelizzo and Stapenhurst, 2004) that the establishment or adoption of oversight tools is a determinant of corruption. Both countries have a similar range of internal parliamentary oversight tools, namely, Public Accounts and other oversight Committees, Question Time, and a Votes of No Confidence (although, as is typical in other countries with a Westminster parliamentary tradition, neither the Parliament of Trinidad \& Tobago nor the Parliament of Grenada play a role in Cabinet formation or dismissal). Similarly, both countries have a similar array of extra-parliamentary institutions, namely an Auditor General (or Audit Department, in the case of Grenada), a number of anti-corruption agencies and Ombudsman.

Thirdly, it has been claimed that it is not the mere existence of these oversight tools that is important, but their effectiveness (Stapenhurst, Pelizzo and Jacobs, 2014). The evidence collected indicates that the key internal and external oversight tools and institutions are somewhat more effective - although still not particularly effective - in Trinidad \& Tobago than in Grenada, with the exception of the anti-corruption agencies, which are considered to be somewhat more effective - but still not particularly effective - in Grenada. The evidence, while limited, also indicates that facilitating factors are also stronger in Trinidad \& Tobago. This is surprising, because ceteris paribus, we would expect, therefore, that corruption would be lower in Trinidad \& Tobago than in Grenada, but we know that is not the case.

Are these results peculiar to the Trinidad \& Tobago and Grenada, or are they generalizable to other small states, especially those in the Caribbean? Clearly, further research is needed.

\section{Executive Domination of Parliament}


As in many Commonwealth countries, there is a perception that government dominates the institutions. To counter this, the institutions must not only be constitutionally independent, but must be perceived independent. Having them report to parliament, as does the Auditor General in Trinidad \& Tobago, would be a first step. The oversight institutions, and indeed parliaments themselves, need financial autonomy and freedom to manage human resources. If oversight institutions are dependent on government departments or public agencies controlled by government, they are likely under-resourced. The general public and public sector officials are mostly unaware of the mandate, work and output of oversight institutions. Again, the Parliament of Trinidad \& Tobago sets a good example of how public awareness can be raised.

To counteract executive dominance, both countries have established Senates which allow for opposition and independent Senators, the latter representing citizen groups and associations. Facing the particular program of no opposition party in the lower chamber, the Grenadian government has established a consultative citizen group. This is an interesting and novel approach for increasing public participation and representation in government, but there is a danger that it could undermine parliament. Parliaments could also pro-actively reach out to civil society groups, with the aim of giving these organizations 'voice' and boosting information from the public that could help strengthen oversight.

\section{Challenges and Solutions Regarding Parliamentary Oversight in Small States}

Our research indicates that the issues and weaknesses in parliamentary oversight are fundamentally different in small countries than in large, and that one cannot generalize across small countries. Most international organizations and donor agencies accept this, but given the lack of evidence about how oversight in small countries works, they fall back on archetype institutions. Evidence presented here confirms that the lessons learned in the UK and Canada are largely irrelevant to small countries, and the lessons in one small country may not easily transfer to other small countries. A country-focused approach is necessary.

One problem that affects both Trinidad \& Tobago and Grenada, and, we suspect, other small Commonwealth states as well, is that the Westminster-form of parliamentary governance is not suited to small states. Certain facets of 'the Westminster' system need to be relaxed, to reflect the contextual differences between the United Kingdom and larger Commonwealth states and smaller island economies. For example, given the small number of elected MPs, joint House-Senate committees should be established and Ministers membership should be allowed to sit on Committees, although not to committees that oversee their departments. Committee membership could include appointees from the public at large, as is the case in some Pacific islands. To overcome the lack of resources, staff from the Auditor General's office could routinely support the $\mathrm{PAC}$ and the limited staff resources in parliament could be supplemented by college or high-school interns. 
A more common problem, which larger states also face, but which is perhaps more acute in small countries is the lack of 'joined-up' oversight. There are a plethora of parliamentary and extraparliamentary institutions undertaking oversight, including parliamentary committees, auditors general, integrity commissions and anti-corruption agencies. Many of these institutions are not independent of government. Parliaments could encourage their greater autonomy and financial independence from government, by advocating that these institutions report to parliament, rather than to the government, and by taking the lead in fostering greater co-ordination and collaboration.

In short, both countries have oversight tools and mechanisms to hold governments to account, and thereby reduce corruption, but their effectiveness has been limited. The recommendations made in this article should enhance their effectiveness. But are they likely to be adopted? Political will to adopt reforms is critical but, as in other countries, inertia often dominates the political environment. Until citizens demand that their elected representatives establish various oversight and anti-corruption mechanisms and ensure these mechanisms are free of political influence and are adequately resourced, the institutions will be 'window dressing' and corrupt actions will continue undeterred and unpunished. The fact that the recent proposed constitutional changes were in Grenada were rejected by the electorate indicates both a the level of popular resistance to fundamental reform, on the one hand and - as was alleged by some survey respondents - the capture of the reform process by vested political interests.

\section{References}

Baldwin, N. (2012). Legislatures of Small States: A Comparative Study. London: Routledge.

Barriteau, V. (2001). The Political Economy of Gender in the Twentieth-Century Caribbean. London: Palgrave.

Barrow-Giles, C. (2010, January). Regional Trends in Constitutional Developments in the Commonwealth Caribbean. Paper presented at the Conflict Prevention and Peace Forum. Retrieved from http://www.cpahq.org/cpahq/cpadocs/Cynthia\%20Barrow.pdf accessed May 1, 2017.

Beetham, D. (2006). Parliament and Democracy in the Twenty-first Century. Geneva: IPU.

Bernard, J. (2017). Grenada: a Corrupt Nation. The New Today. February 6 http://thenewtoday.gd/local-news/2017/02/06/grenada-a-corrupt-nation/\#gsc.tab $=0$ accessed May 1, 2016

Bruzual, Alexander. Society of Corruption. Trinidad and Tobago Newsday online, March 20, 2010, http://www.newsday.co.tt/news/0,117633.html accessed May 1, 2016 
Fisman, R. and R. Gatti. (2000). Decentralization and Corruption: Evidence Across Countries. World Bank Policy Research Paper No. 2290.

Freedom House (2015). Freedom in the World. https://freedomhouse.org/report/freedomworld/2015/grenada Accessed April 5, 2017

Ghany, H. (1994). The Creation of Legislative Institutions in the Commonwealth Caribbean: The Myth of the Transfer of the Westminster Model. Congressional Studies Journal, 2(1), 34-49.

Ghany, H. A. (1999). The Evolution of the Power of Dissolution: The Ambiguity of Codifying Westminster Conventions in the Commonwealth Caribbean. The Journal of Legislative Studies, 5(1), 54-76.

Ghany, H. (2012). The Commonwealth Caribbean Legislatures and democracy. In N. Baldwin Legislatures of Small States: A Comparative Study. London: Routledge

Helfer, L. R. (2002). Overlegalizing Human Rights: International Relations Theory and the Commonwealth Caribbean Backlash Against Human Rights Regimes. Columbia Law Review, 1832-1911.

Islam, R. (2006). The Right to Tell: The Role of Media in Economic Development. Washington, DC: The World Bank.

Kaufmann, D. (2000). Introduction in R.Klitgaard, R. MacLean Abaroa and L. Parris Corrupt Cities: A Practical Guide to Cure and Prevention. Oakland, CA: Institute for Contemporary Studies Press.

Kirton, R. and M. Niki (2010). The Political Culture of Democracy in Trinidad \& Tobago: 2010. Institute of International Relations at UWI, University of the West Indies

Knack, S. and O. Azfar. (2000) Trade Intensity, Country Size and Corruption. Economics of Governance. Vol. 4 (1) pp.1-18.

Kunicova, J and S. Rose-Ackerman. (2005). Electoral Rules and Constitutional Structures as Constraints on Corruption. British Journal of Political Science. Vol.35 (4) pp. 573-606

Mauro, P. (1997) The Effects of Corruption on Growth, Investment and Government Expenditure: a Cross Country Analysis in K.A. Ellio (ed.) Corruption in the Global Economy. Washington, DC: Institute for International Economics

Mechanism for Follow-Up on the Implementation of the Inter-American Convention Against Corruption (MESICIC). (2013) Republic of Trinidad \& Tobago: Final Report. Washington, DC

Mechanism for Follow-Up on the Implementation of the Inter-American Convention Against Corruption (MESICIC). (2014) Grenada: Final Report. Washington, DC 
McGee, D (2002). Te Overseers: Public Accounts Committees and Public Spending. London: Pluto Press.

Mendel, T. (2005) Parliament and Access to Information: Working for Transparent Government. World Bank Institute Working Paper SN 37247.

Mody, J. (2004). Achieving Accountability through Decentralization: Lessons for Integrated River Basin Management. World Bank Policy Research Working Paper, 3346.

NOWGrenada (2015). http://nowgrenada.com/2015/02/new-public-accounts-committee/ Accessed March 28, 2017

Olson, D and M. Mezey ((1991). Legislatures in the Policy Process: Dilemmas of Economic Policy. Cambridge, UK: Cambridge University Press

Olson, D and P. Norton (1996). The New Parliaments of Central and Eastern Europe. London: Frank Cass

ParlAmericas (2012). Strengthening Oversight in the Caribbean: a Roadmap for Developing and Implementing Initiatives in the Region.

ParlAmericas (2014). Strengthening Parliamentary Budget Oversight in the Caribbean (Phase 2).

Parliament of Trinidad and Tobago (2015) First Report of The Joint Select Committee Appointed To Propose A Legislative Framework To Govern The Financing Of Election Campaigns, Fifth Session Of The Tenth Parliament.

Parliament of Trinidad and Tobago (2015). Transformation for Accountability: A ForwardLooking Review of the 10th Parliament of Trinidad \& Tobago.

Pelizzo, R. (2006) Political Parties in R. Stapenhurst, N. Johnston and R. Pelizzo (eds) The Role of Parliament in Curbing Corruption. Washington, DC: World Bank Institute

Pelizzo, R and R. Stapenhurst (2004). Tools for Legislative Oversight. World Bank Research Working Paper: Washington, DC

Pelizzo, R and F. Stapenhurst (2014). Corruption and Legislatures. Abingdon, UK: Routledge

Persson, R. G. Tabellini and F. Trebbi (2001) Electoral Rules and Corruption. National Bureau of Economic Research Working Paper No. 8154

Quist, R. (2008). Public Expenditure and Financial Accountability (PEFA): Public Financial Management Performance Assessment Report.

https://pefa.org/sites/default/files/assements/comments/TT-Dec08-PFMPR-Public.pdf Accessed Aril 2, 2017 
Robinson, W. \& Miko, F. (1994) Political Development Assistance in Central Europe and the Former Soviet Union: Some Lessons From Experience, in: L.D. Longley (ed.) Working Papers on Comparative Legislative Studies, pp. 409-430. Appleton, WI: Research Committee of Legislative Specialists of IPSA.

Rockman, B. (1984). Legislative-Executive Relations and Legislative Oversight. Journal of Legislative Studies. Vol. 9 (3) pp. 387-440.

Schleiter, P and A. Voznaya. (2012). Party System Competitiveness and Corruption. Party Politics Vol. 20 (5). Pp.675-686

Smith, D. (2004). A Question of Trust: Parliamentary Democracy and Canadian Society. Canadian Parliamentary Review. Vol. 27 (1)

Staddon, A. (2013). Activities on strengthening parliamentary practices in Trinidad and Tobago. Study on Parliamentary Scrutiny and Existing Parliamentary Practice. Port-of-Spain

Stapenhurst, R. V. Sahgal, W. Woodley, and R. Pelizzo (2005). Scrutinizing Public Expenditures: Assessing the Performance of Public Accounts Committees in Comparative Perspective. World Bank Policy Research Working Paper No. 3613. Washington, DC.

Stapenhurst, R, R. Pelizzo and K. Jacobs (2014). Following the Money: Comparing Public Accounts Committees. London: Pluto Press

Stapenhurst, F (2011) Legislative Oversight and Curbing Corruption: Presidentialism and Parliamentarianism Revisted. Unpublished thesis. Australian National University.

Stapenhurst, R. (2015) Report on Oversight for the Parliament of Trinidad and Tobago.

Straker, Linda (2017) “Anticorruption Institutions in Grenada Surprised by Ranking” NowGrenada February9th. http://nowgrenada.com/2017/02/anti-corruption-institutions-grenadasurprised-corruption-ranking/ Accessed April 5, 2017.

Taveres, S. (2007). Do Freedom of Information Laws Decrease Corruption? MPRA Paper N. 3650. Rochester: University of Rochester.

Transparency International (2017), http://www.transparency.org/news/feature/corruption perceptions index 2016, accessed March 28, 2017.

Treisman, D. (2000). Causes of Corruption: a Cross Nations Study. Journal of Public Economics. Vol. 76 (3). Pp.399-457

United States Department of Commerce (2016). Trinidad and Tobago - Corruption. https://www.export.gov/article?id=Trinidad-and-Tobago-Corruption accessed May 1, 2016. 
Vassell, L. (2006). Bringing the Broader Context Home: Gender, Human Rights and Governance in the Caribbean. Caribbean quarterly, 51-65.

Wang, V. (2005). The Accountability Function of Parliament in New Democracies: Tanzanian Perspectives. Christer Michelsen Institute Working Paper 2005:2. Bergen, Norway.

Wehner, J. (2004) Back from the Sidelines? Redefining the Contribution of Legislatures to the Budget Cycle. World Bank Institute Working Paper.

Wehner, J. (2010). Legislatures and the Budget Process; the Myth of Fiscal Control. Basingstoke, UK: Palgrave.

Wei, S-J. (2000). Natural Openness and Good Government. National Bureau of Economic Research Working Paper No. 7765.

Wei, S-J and D. Kaufmann (1999) Does 'Grease Money' Speed Up the wheels of Commerce? National Bureau of Economic Research Working Paper No. 7093.

Wiggins, A and J. Shepherd (2010). Assessment of Public Financial Management in Grenada. Using PEFA Public Financial Management Framework. https://pefa.org/sites/default/files/assements/comments/GD-Mar10-PFMPR-Public.pdf accessed March 15, 2016.

World Data Atlas https://knoema.com/atlas accessed Dec 30, 2017

World Values Survey www.worldvaluessurvey.org accessed March 10, 2017 